\title{
7 Carbon Dioxide and Methane Emissions from Estuaries
}

\author{
Gwenaël Abril and Alberto Vieira Borges
}

\begin{abstract}
Carbon dioxide and methane emissions from estuaries are reviewed in relation with biogeochemical processes and carbon cycling. In estuaries, carbon dioxide and methane emissions show a large spatial and temporal variability, which results from a complex interaction of river carbon inputs, sedimentation and resuspension processes, microbial processes in waters and sediments, tidal exchanges with marshes and flats and gas exchange with the atmosphere. The net mineralization of land- and marsh-derived organic carbon leads to high $\mathrm{CO}_{2}$ atmospheric emissions $\left(10-1000 \mathrm{mmol} \cdot \mathrm{m}^{-2} \cdot \mathrm{d}^{-1}\right.$ i.e. $\left.44-44000 \mathrm{mg} \cdot \mathrm{m}^{-2} \cdot \mathrm{d}^{-1}\right)$ from inner estuarine waters and tidal flats and marsh sediments. Estuarine plumes at sea are sites of intense primary production and show large seasonal variations of $\mathrm{pCO}_{2}$ from undersaturation to oversaturation; on an annual basis, some plumes behave as net sinks of atmospheric $\mathrm{CO}_{2}$ and some others as net sources; $\mathrm{CO}_{2}$ atmospheric fluxes in plumes are usually one order of magnitude lower than in inner estuaries. Methane emissions to the atmosphere are moderate in estuaries $\left(0.02-0.5 \mathrm{mmol} \cdot \mathrm{m}^{-2} \cdot \mathrm{d}^{-1}\right.$ i.e. $\left.0.32-8 \mathrm{mg} \cdot \mathrm{m}^{-2} \cdot \mathrm{d}^{-1}\right)$, except in vegetated tidal flats and marshes, particularly those at freshwater sites, where sediments may be $\mathrm{CH}_{4}$-saturated. $\mathrm{CH}_{4}$ emissions from subtidal estuarine waters are the result of lateral inputs from river and marshes followed by physical ventilation, rather than intense in-situ production in the sediments, where oxic and suboxic conditions dominate. Microbial oxidation significantly reduces the $\mathrm{CH}_{4}$ emissions at low salinity $(<10)$ only.
\end{abstract}




\subsection{Introduction}

At the land-ocean interface, estuaries receive large amounts of dissolved and particulate material carried by rivers, including carbon and nutrients. They are highly dynamic systems, characterized by strong physicochemical gradients, enhanced biological activity (both autotrophic and heterotrophic) and intense sedimentation and resuspension. For twenty years it has been well known that riverine material undergoes profound transformations in estuaries before being transferred to the adjacent coastal zone (Wollast 1983). Although such intense biogeochemical processes in estuaries suggested a potential for high gas emissions, very little was known until recently about estuaries and their atmospheric coupling. Intensive gas emissions studies in estuaries started in the 80s in tidal marshes of the US Eastern coast, then in the 90s in various estuarine channels. Recently, the BIOGEST project (BIOGas transfer in ESTuaries, 1996-1999), supported by the European Union, aimed to describe the distributions, cycling and emissions of several biogenic gases in European tidal estuaries (Frankignoulle and Middelburg 2002). The aim of the present paper is to synthesize the recent advances in our understanding of carbon dioxide and methane emissions from estuarine systems. An effort is made to describe the factors controlling the variability of these emissions and to relate them to the carbon cycling in estuaries.

\subsection{Estuaries: Some Useful Definitions for Describing Carbon Cycling and Gas Emissions}

The most exhaustive definition of an estuary was first given by Cameron and Pritchard (1963): "a semi-enclosed coastal body of water, which has free connection with the open sea, and within which seawater is measurably diluted with freshwater derived from land drainage". However, this definition includes many coastal systems with different morphologies. This paper will focus on estuaries classified by Perillo (1995) in two categories: (1) former fluvial valleys, which include coastal plain estuaries and (2) river dominated estuaries. These cases correspond to the majority of large world rivers (Fjords and coastal lagoons will not be considered). Within this definition, the estuary has a channelled or funnelled shape and can be divided in several regions with distinct biogeochemical properties (Fig. 7.1). 


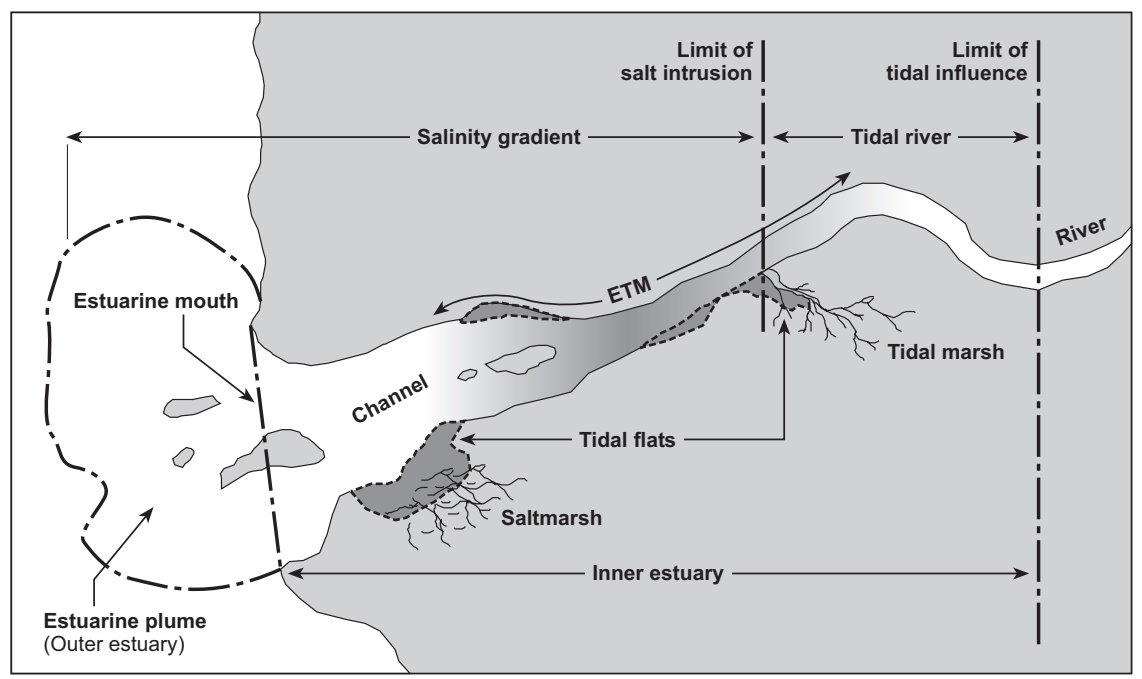

Fig.7.1. Schematic representation of an idealized estuary, with the geographic definitions used in this chapter

Upstream, the inner estuary starts at the limit of the tidal influence, where currents and sedimentary processes become drastically different from those in the river, and stops at the geographic limit of the coast (estuarine or river mouth). The surface of the inner estuary divides into the subtidal area that includes the main channels and tidal flats, that are periodically emerged and in direct contact with the atmosphere due to the tide oscillations. The surface of tidal flats varies with tidal amplitude, estuarine morphology and human transformations (e.g. damming-up). Tidal marshes are wetlands influenced by the tide oscillations and sometimes occupy an important surface all around the inner estuary, as in the case of the US Eastern coast (Cai et al. 1999). The region of the inner estuary, submitted to the tide but containing only freshwater is generally called the tidal river, and may include freshwater tidal flats and marshes. Downstream, the mixing of freshwater with seawater starts inside the geographical limit of the coast, a region that also comprises tidal flats and saltmarshes, and continues at sea, in an area called the plume (Ketchum 1983). The surface of this plume is commonly defined on the basis of salinity in surface waters, a value of 1 lower than the adjacent oceanic basin being arbitrary used as the offshore boundary (e.g. Borges and Frankignoulle 2002). Although the surface of the inner estuary is easy to evaluate, the one of the plume is highly variable, both in a given system (seasonal variability) and from one system to another. River-dominated estuaries like the Amazon, (Brazil), 
the Mississippi (US) and the Rhine (The Netherlands) have an extended plume, salinity at the mouth being relatively low. By contrast, in coastal plain estuaries with moderate river discharge like the Gironde (France), the Scheldt (Belgium/Netherlands) and the Thames (UK), a large part of the salinity gradient is located within the inner estuary.

The residence time of freshwaters in an estuary may vary from days to months, depending on the river discharge -that lowers it- and the tidal amplitude -that increases it-. Estuaries are sites of intense sedimentation in particular of fine material eroded from land. Due to the asymmetry of the tide, to density gradients and to flocculation processes when freshwater mixes with seawater, an estuarine turbidity maximum (ETM) is commonly found, often most concentrated at low salinities (Allen et al. 1980; Uncles 2002). The high currents (sometimes exceeding $2 \mathrm{~m} \cdot \mathrm{s}^{-1}$ ) and their rapid change at the tidal and fortnightly timescales result in intense sedimentation and resuspension cycles in ETMs, where residence time of suspended matter may exceed several years before being definitively sedimented or exported to the adjacent shelf (Allen et al. 1980; Uncles 2002). Tidal flats and marshes exchange sediment, water and porewater with the adjacent subtidal estuary, at the tidal, fortnightly and seasonal times scales.

\subsection{Organic Carbon Sources and Mineralization in Estuaries}

Both aquatic and terrestrial organic matter are found in estuaries. Rivers carry terrestrial soil particles, humic substances and litters from land, but also freshwater phytoplankton and domestic loads (sewage) (Wollast 1983; Meybeck 1993; Veyssy et al. 1999; Abril et al. 2002). A large part the riverine particulate organic carbon is lost during its transit in estuaries (Ittekkot and Laane 1991; Keil et al. 1996; Abril et al. 2002). Indeed, on an annual basis, total respiration exceeds gross primary production in estuaries that are net heterotrophic ecosystems (Smith and Hollibaugh 1993; Gattuso et al. 1998). Mineralization affects in priority the most labile material (phytoplankton and sewage) but also a significant fraction of terrestrial organic matter (Keil et al. 1997; Veyssy et al. 1999). Estuarine sedimentary environments like ETMs and deltaic muds are characterized by frequent sedimentation/erosion events, which induce redox oscillations and particle mixing and favor particulate organic matter decomposition and recycling (Aller 1998; Abril et al. 1999).

In tidal flats and marshes, like in many wetlands worldwide, primary production by microphytobenthos and periodically submerged plants 
(rooted macrophytes) is intense (Nienhuis 1992). It constitutes a major source of organic matter to the flat and marsh sediments (Goni and Thomas 2000; Delaune and Pezeshki 2003), but also to the adjacent estuarine waters and sediments, tidal flushing resulting in an outwelling process of carbon and nutrients (Dame et al. 1986). Consequently, heterotrophic activity in the adjacent estuary is also partly fueled by tidal inputs from flats and marshes. Inversely, intertidal sediments trap estuarine suspended particles, especially when they are colonized by plants (Widdows et al. 2000). This leads to high organic carbon sedimentation rates of a mixture of relatively organic-poor particles from the ETM and highly reactive plant debris (Goni and Thomas 2000). Globally, tidal marshes appear to be slightly autotrophic (Gattuso et al. 1998), meaning that more organic matter is produced by plants than is remineralized in the sediment and exported to adjacent waters. Little is known about the net metabolism of tidal flats, which is probably different from marshes, owing to greater carbon exchanges with the estuarine channel.

In riverine plumes, turbidity is much lower than in inner estuaries. In many sites, like in the Gironde and Loire estuaries in France, depending on river discharge, light starts seasonally to penetrate deeper into the water upstream the estuarine mouth (Fig. 7.1), and the lower part of the inner estuary has similar characteristics as the plume at sea. This availability of light, together with the input of nutrients from the river and the stratification of waters due to vertical salinity gradients, create favorable conditions for phytoplankton blooms (Cloern 1996). In addition, enrichment in nutrients by agricultural practices in watershed has significantly modified the intensity and community structure of these blooms as exemplified by the Mississippi plume (Justic et al. 1995) and the Southern North Sea coast (Reid et al 1990). However, in macrotidal tidal systems and especially those with large ETMs, phytoplankton biomass in estuarine plumes represents a seasonal carbon stock one to two orders of magnitude lower than the terrestrial organic matter in the ETM (Abril et al. 2002).

\subsection{Estuarine Specificity for Gas Transfer}

The flux of a gas across the air-water interface is governed by the following equation:

$$
\mathrm{F}=k \alpha \Delta \mathrm{p}
$$

where $\alpha$ is the solubility coefficient of the gas, $\Delta \mathrm{p}$ is the air-water gradient of the gas partial pressure and $k$ is the gas transfer velocity. For sparingly soluble gases such as carbon dioxide and methane, $k$ mainly depends 
on turbulence in the liquid phase (Wanninkhof 1992) that is affected by a number of forcings in estuarine environments. As in the ocean and in lakes, wind stress is the main generator of water turbulence. For that reason, a parameterization of $k$ as a function of wind speed is generally used to calculate gas fluxes from $\Delta \mathrm{p}$ in estuaries (Marino and Howard 1993; Raymond and Cole 2001). However, tidal currents may also contribute to water turbulence, especially in inner estuaries with shallow waters and high frictions on the bottom (rugosity). In streams, the generation of turbulence by friction due to flow over the bottom dominates. Therefore, $k$ is parameterized as function of the ratio between water velocity and water depth (O'Connor and Dobbins 1958). In a recent review that compiles measurements in various systems, Raymond and Cole (2001) suggested that $k$ could be significantly higher in estuaries than in open oceanic waters at the same wind speed. Borges et al. (2004a) calculated $k$ from $\mathrm{CO}_{2}$ flux measurements with a floating chamber in three European estuaries. They found very different relationships between $k$ and wind speed, with significantly higher values in the two macrotidal systems than in the microtidal system (Fig. 7.2). In addition, using low to moderate wind speed data, they calculated a contribution of water current, consistent with the formulation of O'Connor and Dobbins (1958) in streams. In the macrotidal Scheldt estuary, the tidally and yearly integrated contribution of water currents was estimated to account for $24 \%$ of the total gas transfer velocity, the remaining part being attributed to wind (Borges et al. 2004b). Zappa et al. (2003) carried out concomitant measurements of $k$ with the gradient flux technique and of water turbulence in the aqueous boundary layer in a macrotidal estuary (Plum Island Sound) over a tidal cycle during a low wind day $\left(1.9 \mathrm{~m} \cdot \mathrm{s}^{-1}\right)$. They found a large variation of $k$ from 2.2 to $12.0 \mathrm{~cm} \cdot \mathrm{h}^{-1}$ that correlated well with tidal speed and turbulence. The tidal averaged $k$ was $6.2 \pm 0.4$, that is 1.6 times higher than the one calculated from wind speeds with the Raymond and Cole (2001) relationship. The comparison of all these different $k$-wind relationships (Fig. 7.2) clearly suggests the occurrence of another controlling factor besides tidal currents, which is site-specific. Fetch (diameter of the inner estuary in the direction of the prevailing wind) is probably a good candidate (Borges et al. 2004a submitted manuscript). A long fetch favors the formation of waves, eventually forming whitecaps and enhances the potential for wind to favor gas transfer. An interesting result was obtained recently by Kauppila et al. (2003), who analysed a database of chemical, meteorological and morphometric parameters from 19 microtidal Finnish estuaries. They concluded that fetch could explain $30 \%$ of the variation in oxygen concentrations, being the second variable after a function of mean water depth and the percentage of watershed under agriculture (55\%). 


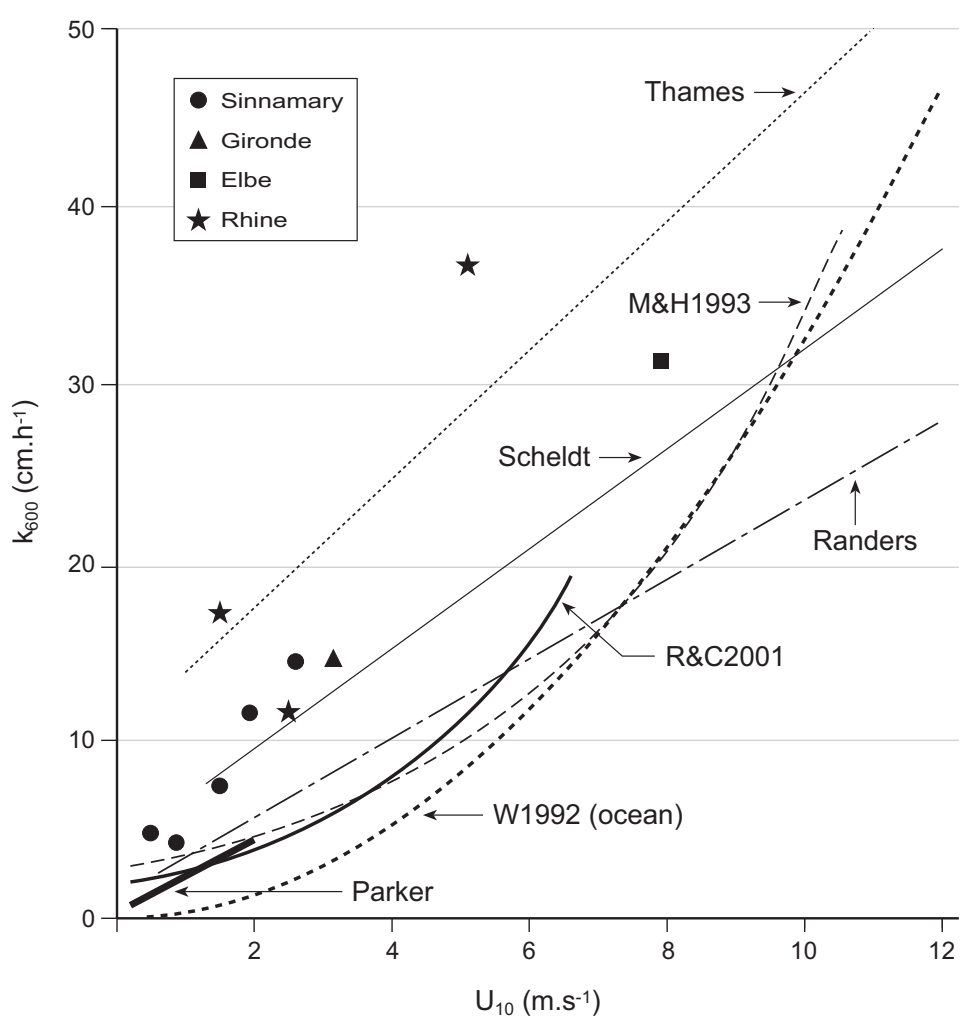

Fig. 7.2. Relationships between the gas transfer velocity $k_{600}$ (normalized to a Schmidt number of 600) and the wind speed at $10 \mathrm{~m}$ height obtained in estuaries with different tidal range (TR) and average depth (AD).

The relationships are from the following references: W1992: Wanninkhof (1992) for the ocean; R\&C2001: Raymond and Cole (2001) who compiled data in various estuaries with different techniques; M\&H1993: Marino and Howard (1993) based on floating chamber oxygen flux measurements in the Hudson estuary (US-New York, TR $1.3 \mathrm{~m}$, AD $15 \mathrm{~m}$ ) and various rivers; Parker estuary (US-Massachussets, TR 2.9 m, AD 4 m): Carini et al. (1996) based on a SF 6 experiment; Randers Fjord estuary (Denmark, TR 0.2, AD 2 m), Scheldt estuary (Belgium/Netherlands, TR $3.8 \mathrm{~m}, \mathrm{AD} 10 \mathrm{~m}$ ) and Thames estuary (UK, TR $4.5 \mathrm{~m}, \mathrm{AD} 8 \mathrm{~m}$ ): Borges et al. (2004a), based on floating chamber $\mathrm{CO}_{2}$ flux measurements; Gironde (France, TR $4 \mathrm{~m}, \mathrm{AD} 10 \mathrm{~m}$ ), Elbe (Germany, TR $3 \mathrm{~m}, \mathrm{AD} 9 \mathrm{~m}$ ) and Rhine (The Netherlands, TR $2.5 \mathrm{~m}, \mathrm{AD} 11 \mathrm{~m}$ ) are based on floating chamber $\mathrm{CO}_{2}$ flux measurements (data were averaged over wind speed bins of $1 \mathrm{~m} \cdot \mathrm{s}^{-1}$ ) (Borges et al. unpublished data). Sinnamary estuary (French Guiana, TR $1.8 \mathrm{~m}$, AD $3.5 \mathrm{~m}$ ) are some preliminary results derived from 5 individual methane flux measurements at low wind speeds (Guérin, Abril et al. unpublished data). 
Kremer et al. (2003) and Borges et al. (2004a) concluded that a simple parameterization of $k$ as a function of wind speed is still appropriate for estuaries, but it is site-specific, each relation integrating a combination of current, depth and fetch effects. They added that the floating chamber method, when used cautiously (Lagrangian measurements in a drifting boat and at moderate wind speed) provides a convenient and inexpensive approach for quantifying these cross-system differences. Anyhow, there is an evident need for techniques of gas exchange flux measurements adapted to the physical characteristics of estuaries. Classic natural or released tracer techniques provide gas transfer velocity estimates at time scales $(>1 \mathrm{~d})$ that do not allow to adequately describe the short term variability (min to $h$ ) of $k$ in these very dynamic environments. Direct techniques as those used by Zappa et al (2004) (gradient flux, dissipation rate and controlled flux) appear promising if they can be adapted to highly dynamic environments with high currents, wind and waves.

Nevertheless, all these recent advances in our understanding of gas exchange processes converge to the idea that gas transfer velocities in estuaries are higher than in lakes and in the ocean at a same wind speed. In addition to temporal variations, $k$ is highly variable spatially. Indeed, tidal currents, depth and wind are geographically highly variable inducing large differences $k$ (Borges et al. 2004b). Dissolved gases can consequently be advected from less dynamic regions (e.g. from tidal marshes) and get further ventilated in more dynamics regions (e.g. the main channel and the plume). This is of major importance when interpreting the spatial distributions of gases in estuarine waters, and when calculating carbon budgets that include input from the river, exchanges with tidal flats and marsch, and outputs to the atmosphere and the ocean.

\subsection{Carbon Dioxide Emissions}

As heterotrophic ecosystems, estuaries are a source of $\mathrm{CO}_{2}$ to the atmosphere (Frankignoulle et al. 1996; 1998). Indeed, oxygen deficits and $\mathrm{CO}_{2}$ supersaturations are common features in estuaries. Examples of classical distribution of $\mathrm{pCO}_{2}$, oxygen and $\mathrm{CO}_{2}$ fluxes to the atmosphere are shown in Fig. 7.3. River waters entering estuaries have $\mathrm{pCO}_{2}$ generally higher than the atmosphere, due to organic carbon mineralization in soils, river waters and sediments (Jones and Mulholland 1998a; Neal et al. 1998; Cole and Caraco 2001; Richey et al. 2002). Nevertheless, $\mathrm{pCO}_{2}$ further increases in estuaries, especially in the tidal river and at low salinities (Fig. 7.3). This region often corresponds to the location of the ETM where 

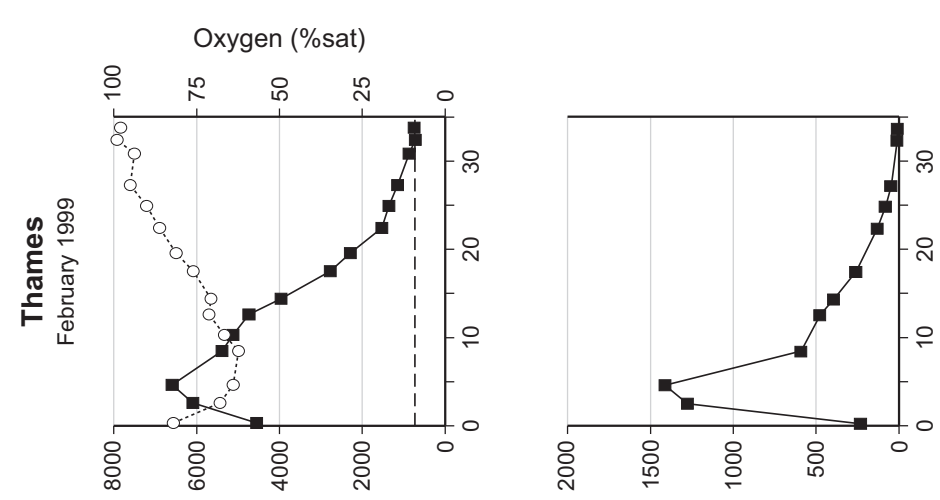

.

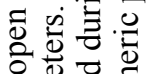

光: की

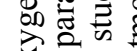

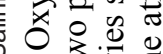

글

हิ के न

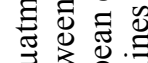

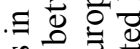

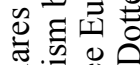

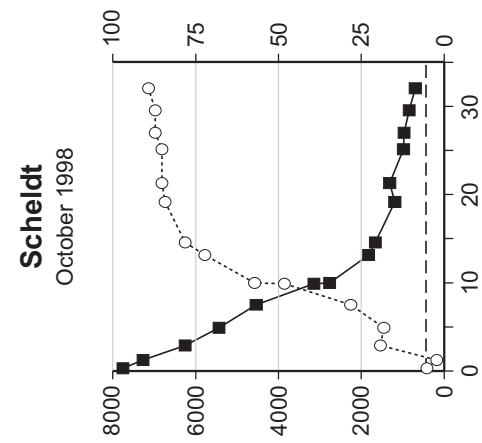

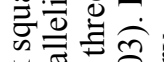
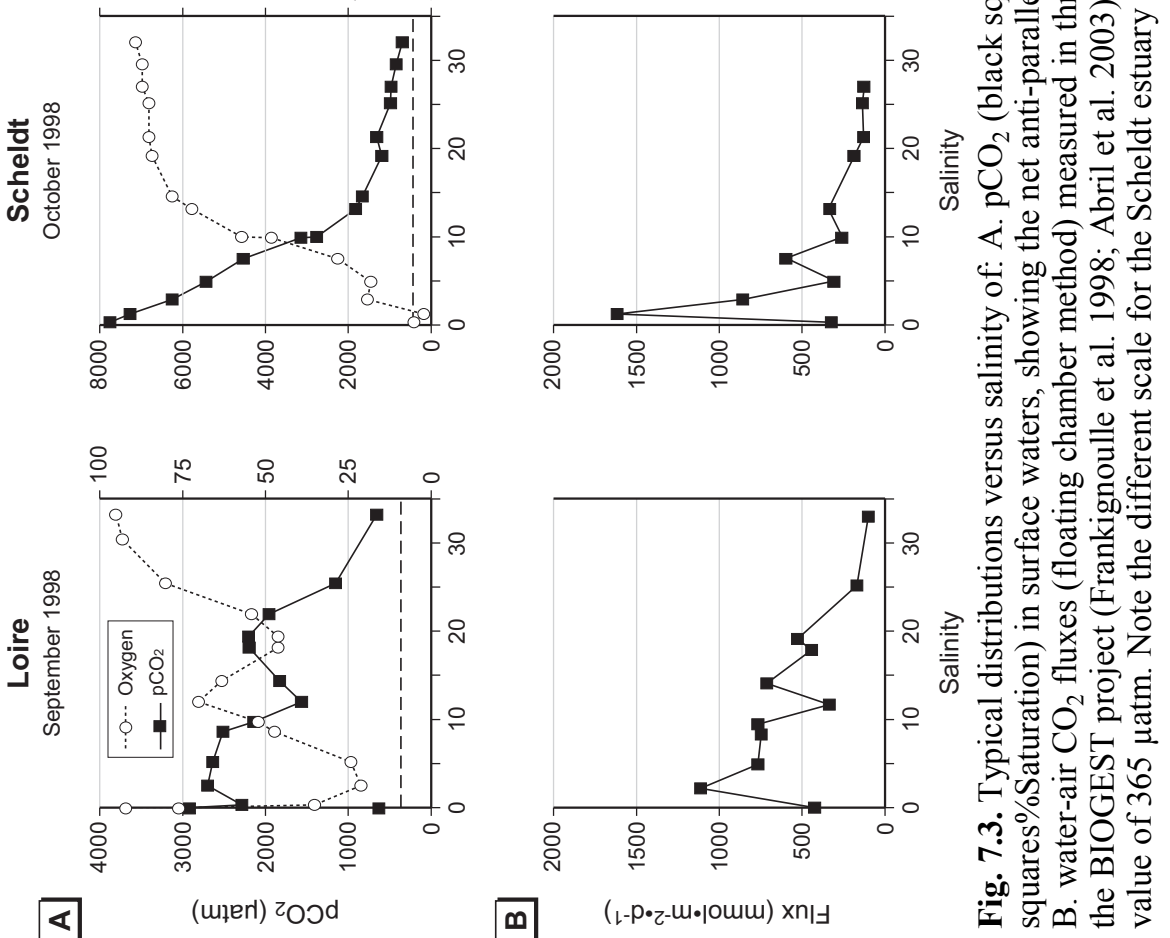

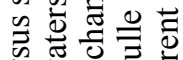

¿ᄒ丶

ص 沓

-잌웛

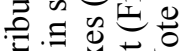

泀皇

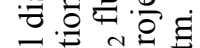

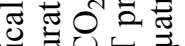

总至仙的

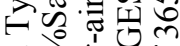

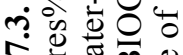

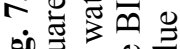

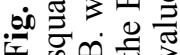


heterotrophy is intense as revealed by important oxygen depletions. Indeed, in ETM, steep light extinction inhibits photosynthesis, whereas high suspended matter enhance respiration, heterotrophic bacteria occurring in majority attached to the particles (Crump et al. 1998; Goosen et al. 1999).

Table 7.1 summarizes $\mathrm{pCO}_{2}$ and $\mathrm{CO}_{2}$ fluxes measured so far in inner estuaries. Besides some differences from one site to another, it can be seen that a large oversaturation is the general situation and that $\mathrm{CO}_{2}$ fluxes to the atmosphere can occasionally reach one mol. $\mathrm{m}^{-2} \cdot \mathrm{d}^{-1}$ (Fig. 7.3). Based on fluxes measured with the floating chamber method in nine European estuaries and during 26 cruises, Frankignoulle et al. (1998) proposed a realistic average $\mathrm{CO}_{2}$ flux of $170 \mathrm{mmol} \cdot \mathrm{m}^{-2} \cdot \mathrm{d}^{-1}\left(\right.$ i.e. $\left.7500 \mathrm{mg} \cdot \mathrm{m}^{-2} \cdot \mathrm{d}^{-1}\right)$ for inner estuaries.

Tidal marshes are generally a net sink of atmospheric $\mathrm{CO}_{2}$ leading to a net burial of organic matter in the sediment (Gattuso et al. 1998; Delaune and Pezeshki 2003). However, due to an intense recycling of sedimentary organic matter, sediments and soils from tidal flats and marshes emit large amounts of $\mathrm{CO}_{2}$, directly to the atmosphere at low tide and across a water column of variable height when submerged. It can be seen in Table 7.2 that direct sediment-atmosphere fluxes measured at low tide in flats and marshes fit well within the range of water-atmosphere fluxes measured in subtidal inner estuaries (Table 7.1).

Lateral transport of $\mathrm{CO}_{2}$ from tidal flats and marshes can also significantly contribute to the high $\mathrm{pCO}_{2}$ in adjacent estuarine waters. In the freshwater intertidal marshes complex of five rivers in the southeastern U.S., Cai et al. (1999) found that respiratory activity in estuarine waters and sediments was not sufficient to account for the observed oxygen concentrations and $\mathrm{pCO}_{2}$. In their system, advection of excess $\mathrm{CO}_{2}$ from marshes with tidal flushing largely contributes to the $\mathrm{CO}_{2}$ flux in the main channel. This in due to the conjunction of two facts: high respiratory activity in marsh sediments; and lower gas exchange rates in the marsh than in the channel.

Another important process for carbon cycling in inner estuaries is a net production of alkalinity at low to moderate salinities, observed in several systems (Abril et al. 1999; 2003; Cai et al. 2000; Raymond et al. 2000; Bouillon et al. 2003). Production of alkalinity from dissolved $\mathrm{CO}_{2}$ generated during respiration represents a long term sink for atmospheric $\mathrm{CO}_{2}$. Basically, there are two potential processes (Stumm and Morgan 1996) that can result in a long term alkalinity production in estuaries: 1) carbonate dissolution, when dissolved $\mathrm{CO}_{2}$ reacts with calcium carbonate particles to produce two bicarbonate anions and dissolved calcium; this process is responsible for large alkalinity generations in the Loire (Abril et al. 


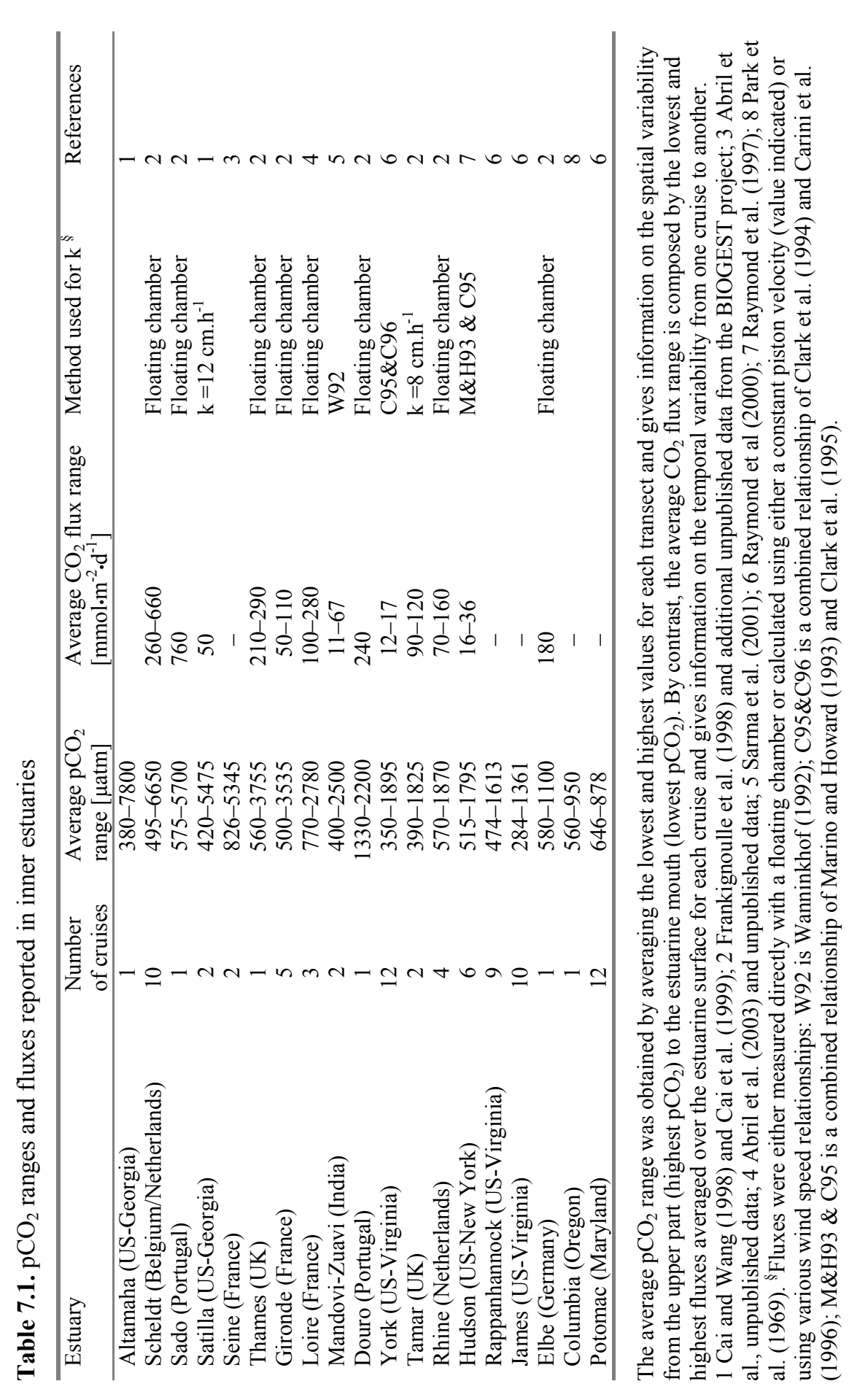


Table 7.2. $\mathrm{CO}_{2}$ emission from tidal marshes and flats soils and sediments at various salinities

\begin{tabular}{|c|c|c|c|}
\hline Site & Salinity & $\begin{array}{l}\mathrm{CO}_{2} \text { emission } \\
{\left[\mathrm{mmol} \cdot \mathrm{m}^{-2} \cdot \mathrm{d}^{-1}\right]}\end{array}$ & Reference \\
\hline $\begin{array}{l}\text { Oyster Landing salt marsh } \\
\text { (US-South Carolina) }\end{array}$ & $5-7$ & $50-75$ & 1 \\
\hline \multirow{2}{*}{$\begin{array}{l}\text { Dipper Harbour salt marsh } \\
\text { (Canada-New Brunswick) }\end{array}$} & $20.6-23.5$ & 40 & 2 \\
\hline & $31-35$ & 60 & 2 \\
\hline \multirow{2}{*}{$\begin{array}{l}\text { Scheldt estuary, tidal flats } \\
\text { (Belgium/the Netherlands) }\end{array}$} & 1 & 375 & 3 \\
\hline & 25 & 50 & 3 \\
\hline $\begin{array}{l}\text { Mississipi deltaic coastal marshes } \\
\text { (US-Louisiana) }\end{array}$ & $3-5$ & $100-140$ & 4 \\
\hline
\end{tabular}

1 Morris and Whiting (1986); 2 Magenheimer et al. (1996); 3 Middelburg et al. (1996); 4 Delaune and Pezeshki (2003).

2003) and in the Godavari estuary in India (Bouillon et al. 2003). In the Loire ETM, carbonate dissolution is enhanced by the presence of authigenic carbonate carried by the eutrophic river and increases by $\sim 30 \%$ the summer alkalinity export to the ocean (Abril et al. 2003); 2) diagenetic processes in anoxic sediments; primary diagenetic reactions (nitrate, manganese, iron or sulfate reductions) consume protons and produce alkalinity, whereas secondary reactions (ammonia, manganese, iron and sulfide oxidations) release protons and decrease the alkalinity. If primary reactions are incompletely compensated by secondary reactions (e.g. if iron-sulfides precipitate and get buried), a net release of alkalinity occurs. In addition, anaerobic fermentative processes (e.g. decarboxilation) may spontaneously generate alkalinity. For that reason, significant amounts of alkalinity were found to be outwelled from tidal marshes anoxic sediments (Cai et al. 2000; Raymond et al. 2000). There is a need today for a better understanding of the alkalinity generation by these two kinds of processes in estuaries.

The outer estuary has substantial different properties with respect to carbon dioxide, intense phytoplanktonic blooms consuming significant amounts of dissolved $\mathrm{CO}_{2}$. $\mathrm{pCO}_{2}$ in estuarine plume depends on its primary production/respiration balance but also on the quantity of excess dissolved $\mathrm{CO}_{2}$ advected from the inner estuary. Thus, $\mathrm{CO}_{2}$ atmospheric exchanges in plumes are affected by a large number of parameters, among which, the river discharge, the degree of heterotrophy in the inner estuary, the availability of nutrients and light and the stratification of the water column are the most important. Consequently, $\mathrm{pCO}_{2}$ is highly variable in 
plumes both seasonally in a given system and from one system to another. During 13 cruises in 7 European Atlantic and North Sea estuarine plumes Frankignoulle et al. (1998) observed $\mathrm{pCO}_{2}$ variations from $240 \mu \mathrm{atm}$ in the Scheldt plume at salinity 34 in March 1997 to $1330 \mu \mathrm{atm}$ at the mouth of the Douro (salinity 9) in September 1997. Borges and Frankignoulle (2002) carried out intensive $\mathrm{pCO}_{2}$ measurements during three years in the Scheldt plume, a highly eutrophic region of the Southern North Sea. They could observe important $\mathrm{CO}_{2}$ undersaturation $\left(\mathrm{pCO}_{2}\right.$ down to $\left.90 \mu \mathrm{atm}\right)$ in April and May, associated with a high algal biomass. However, oversaturation $\left(\mathrm{pCO}_{2}\right.$ up to $\left.700 \mu \mathrm{atm}\right)$ was the general situation the rest of the year, $\mathrm{CO}_{2}$ advection from the inner Scheldt and mineralization of phytoplanktonic carbon being very important. They concluded that the Scheldt plume behaves as a source of $\mathrm{CO}_{2}$ with an annually integrated water-air flux of $+4 \mathrm{mmol} \cdot \mathrm{m}^{-2} \cdot \mathrm{d}^{-1}$. Brasse et al. (2002) carried out similar measurements in the Elbe plume (German Bight, southern North Sea) and found undersaturation (down to $140 \mu \mathrm{atm}$ ) was predominant. However, their dataset was restricted to the spring and summer period, and $\mathrm{pCO}_{2}$ higher than $500 \mu \mathrm{atm}$ occurred during their only cruise with high river runoff. Finally, Ternon et al. (2000) showed that the plume of the Amazon, that may extend up to $2000 \mathrm{~km}$ northwestward along the coast of Brazil, French Guiana and Surinam, behaves as a large sink of atmospheric $\mathrm{CO}_{2}$ with $\mathrm{pCO}_{2}$ values ranging between 200 and $400 \mu \mathrm{atm}$. Körtzinger (2003) observed similar $\mathrm{pCO}_{2}$ values and using sea surface salinity data, calculated an average integrated flux for the Amazon river plume of $-1.4 \mathrm{mmol} \cdot \mathrm{m}^{-2} \cdot \mathrm{d}^{-1}$. The significance of $\mathrm{CO}_{2}$ fluxes in estuarine plumes in the overall estuarine system is difficult to apprehend because few studies have investigated both inner and outer estuaries. Borges and Frankignoulle (2002) showed that the $\mathrm{CO}_{2}$ emission from the Scheldt plume represents 17 to $29 \%$ of the estimate for the Scheldt inner estuary. On the other hand, Körtzinger (2003) estimated the sink of $\mathrm{CO}_{2}$ in the Amazon plume to $0.01410^{15} \cdot \mathrm{g} \cdot \mathrm{C} \cdot \mathrm{yr}^{-1}$ that is more than one order of magnitude smaller than the total $\mathrm{CO}_{2}$ source of $0.510^{15} \mathrm{~g} \cdot \mathrm{C} \cdot \mathrm{yr}{ }^{-1}$ from Amazonian rivers and wetlands (Richey et al. 2002). All these studies reveal the variable properties of estuarine plumes with respect to air-sea $\mathrm{CO}_{2}$ exchange. They also illustrate the high temporal variability in each site and the necessity of sustained investigation in order to adequately quantify the $\mathrm{CO}_{2}$ exchanges between estuarine plumes and the atmosphere, at the regional and global scale. 


\subsection{Methane Emissions}

Methane emissions from estuarine surfaces vary over a wide range of spatial and temporal scales. The processes of methane production, transport, oxidation and emission are complex and very different in tidal flats and marshes compared to estuarine main channels. However, these processes have been studied in several systems worldwide so it becomes possible nowadays to give a general picture of methane cycling and emissions in estuaries.

Similarly to continental wetlands (Richey et al. 1988), methane emissions from tidal flats and marshes are high (Bartlett et al. 1987; Chanton et al. 1989; Kelley et al. 1995; Middelburg et al. 1996), with annual averages typically in the range of few mmol. $\mathrm{m}^{-2} \cdot \mathrm{d}^{-1}$ (Table 7.3). Methane production is particularly intense in tidal flats and marshes because of large inputs of organic matter at anoxic depths by plants rooted in the sediments (Kelley et al. 1995; Van der Nat and Middelburg 2000). Methane emissions vary seasonally, closely following the growing, maturing and dying cycle of plants (Bartlett et al. 1987; Kelley et al. 1995). Another crucial parameter is the availability of sulfate that increases with salinity. Sulfate availability allows sulfate-reducing bacteria to outcompete methanogenic bacteria in anoxic sediments (Capone and Kiene 1988). For that reason, methane emissions from estuarine tidal flats (Middelburg et al. 1996) and marshes (Bartlett et al. 1987) decrease by two orders of magnitude from fresh-water sites to saltwater sites (Table 7.3). Methane in tidal flats and marshes is emitted to the atmosphere by diffusion, ebullition (Chanton et al. 1989) and possibly transport through plants (Kelley 1995). In freshwater tidal marshes and flats, ebullition may equal diffusion and the variations in hydrostatic pressure induced by the diurnal tidal cycle control the ebullition rate (Chanton et al. 1989; Kelley et al. 1995; Middelburg et al. 1996). Finally, the tidal flushing of flats and marshes may export laterally large quantities of methane to the adjacent estuarine waters (Bartlett et al. 1985; Kelley et al. 1995).

Methane concentrations in estuarine waters vary over a wide range but are almost always higher than the atmospheric equilibrium $\left(2-3 \mathrm{nmol} \cdot \mathrm{l}^{-1}\right)$ and generally show a decrease from fresh to salt waters (De Angelis and Lilley 1987; Scranton and McShane 1991; De Angelis and Scranton 1993; Bange et al. 1998; Sansone et al. 1998 and 1999; Upstill-Goddard et al. 2000; Jayakumar et al. 2001; Middelburg et al. 2002; Abril and Iversen 2002). This general pattern is due to river inputs which are a major contributor to the methane found in estuarine waters. In river main streams, 


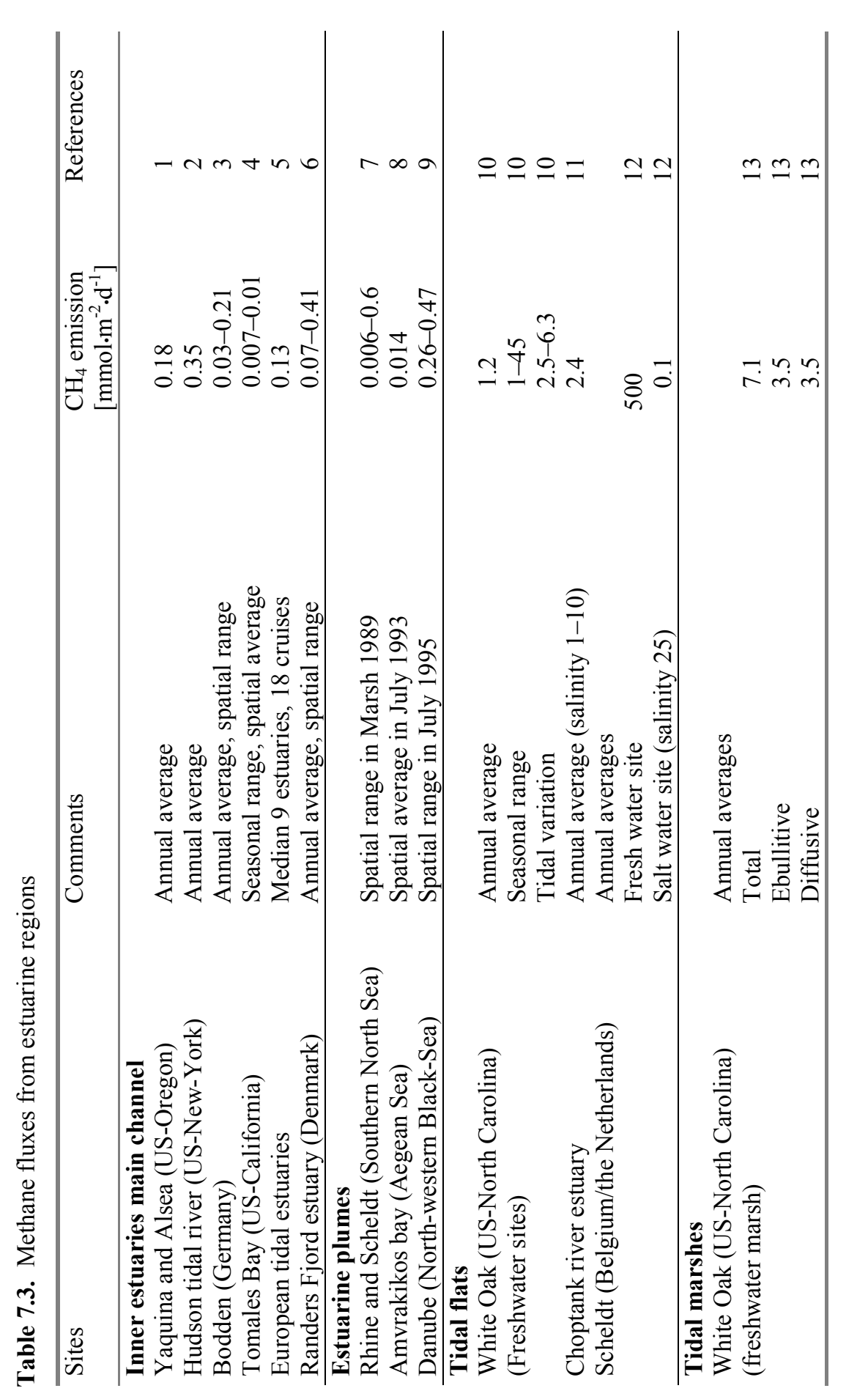




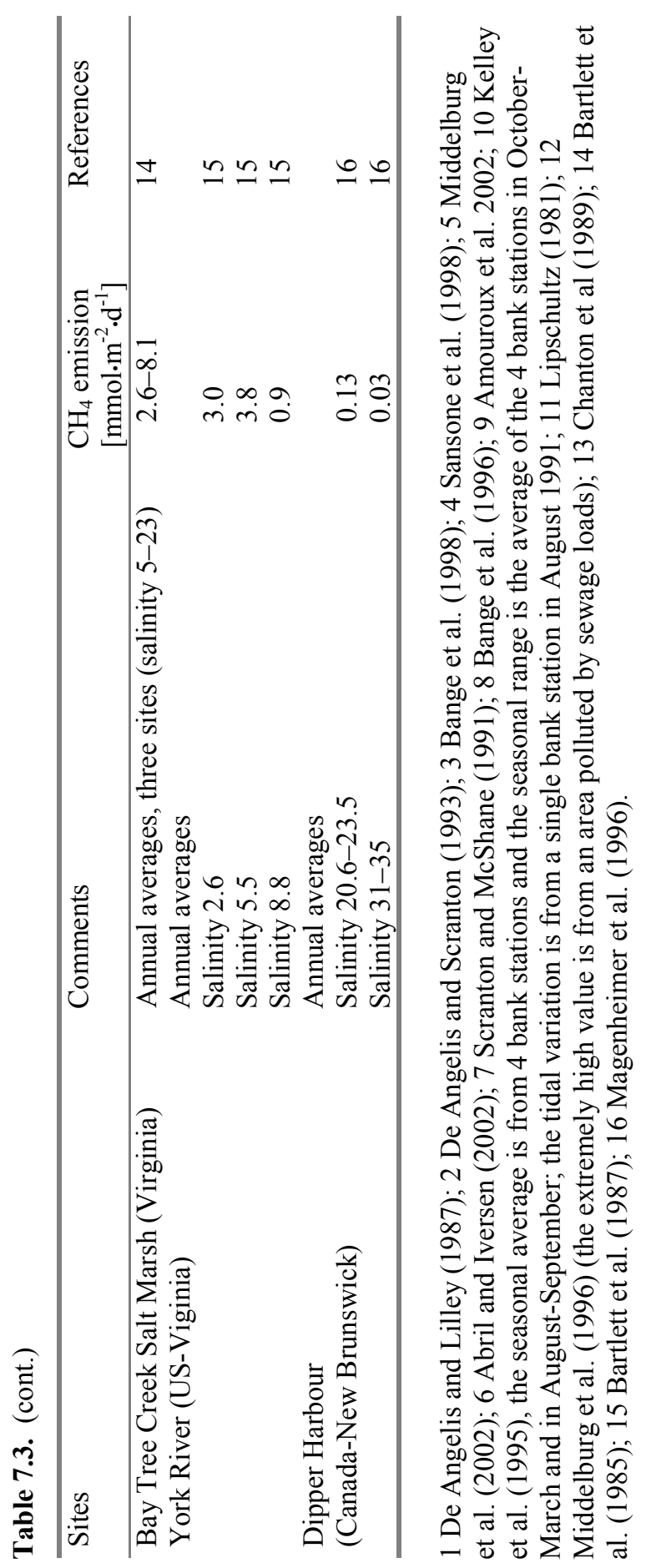


the lowest methane concentration reported so far was $5 \mathrm{nmol} \cdot \mathrm{l}^{-1}(200 \%$ saturation relative to the atmosphere) in the McKenzie River (De Angelis and Lilley 1987) and the highest was $2.4 \mu \mathrm{mol}^{-1} \mathrm{l}^{-1}$ (90 000\% saturation) in the Picassic River (Sansone et al. 1999), both systems also showing large temporal variations (for recent compilations of river concentrations refer to Upstill-Goddard et al. 2000 and Middelburg et al. 2002). This supersaturation is mostly due to inputs of methane-rich waters from surrounding anoxic environments rather than important production in the river system itself. In particular, groundwater inputs (Jones and Mulholland 1998b) and transport of river waters over wetlands and floodplains (Richey et al. 1988) are major mechanisms that contribute to the high methane concentrations in rivers.

As discussed previously, due to tidal currents and exposure to wind, gas exchange rates are generally much higher in estuarine main channels and plumes than in rivers and in tidal marshes. This results in a physical ventilation of a large part of the methane carried by rivers or advected from tidal marshes, both in inner estuaries (Upstill-Goddard et al. 2000; Middelburg et al. 2002) and in plumes at sea (Scranton and McShane 1991, Bange et al. 1994). Among the methane distributions observed during the BIOGEST project, the one in the Thames estuary (Fig. 7.4) is typical of a dominant river input followed by an emission (and oxidation, see below) in the upper part of the estuary. By contrast, in the Scheldt and Sado estuaries (Fig. 7.4), the increases in concentrations observed at salinities 20-30 are examples of significant input from tidal flats, highly extended at these salinities in both estuaries (Middelburg et al. 2002).

Methane fluxes in inner estuaries and plumes in Table 7.2 are around $0.2 \mathrm{mmol} \cdot \mathrm{m}^{-2} \cdot \mathrm{d}^{-1}$. A simple calculation that considers this flux value and a concentration of $200 \mathrm{nmol} \cdot \mathrm{l}^{-1}$ in an inner estuary with a $10 \mathrm{~m}$ depth, leads to a turnover time of methane in the water column of 10 days, relative to atmospheric emission alone. This is shorter than the residence time of waters in many macrotidal inner estuaries. It means that due to atmospheric emission alone, very little methane from rivers or freshwater marshes reaches the estuarine mouth in long residence time systems like the Hudson (US-New York), Gironde and Loire (France), Scheldt (Belgium/Netherlands), etc. Thus, more methane needs to be produced in the inner estuary in order to export methane to the plume (De Angelis and Scranton 1993; Middelburg et al. 2002). By contrast, in the case of the Rhine (The Netherlands), a river-dominated system with high methane concentrations in freshwater and a short residence time (2-7 days) in the inner estuary, riverine methane can be tracked over long a distance offshore (Scranton and McShane 1991). 


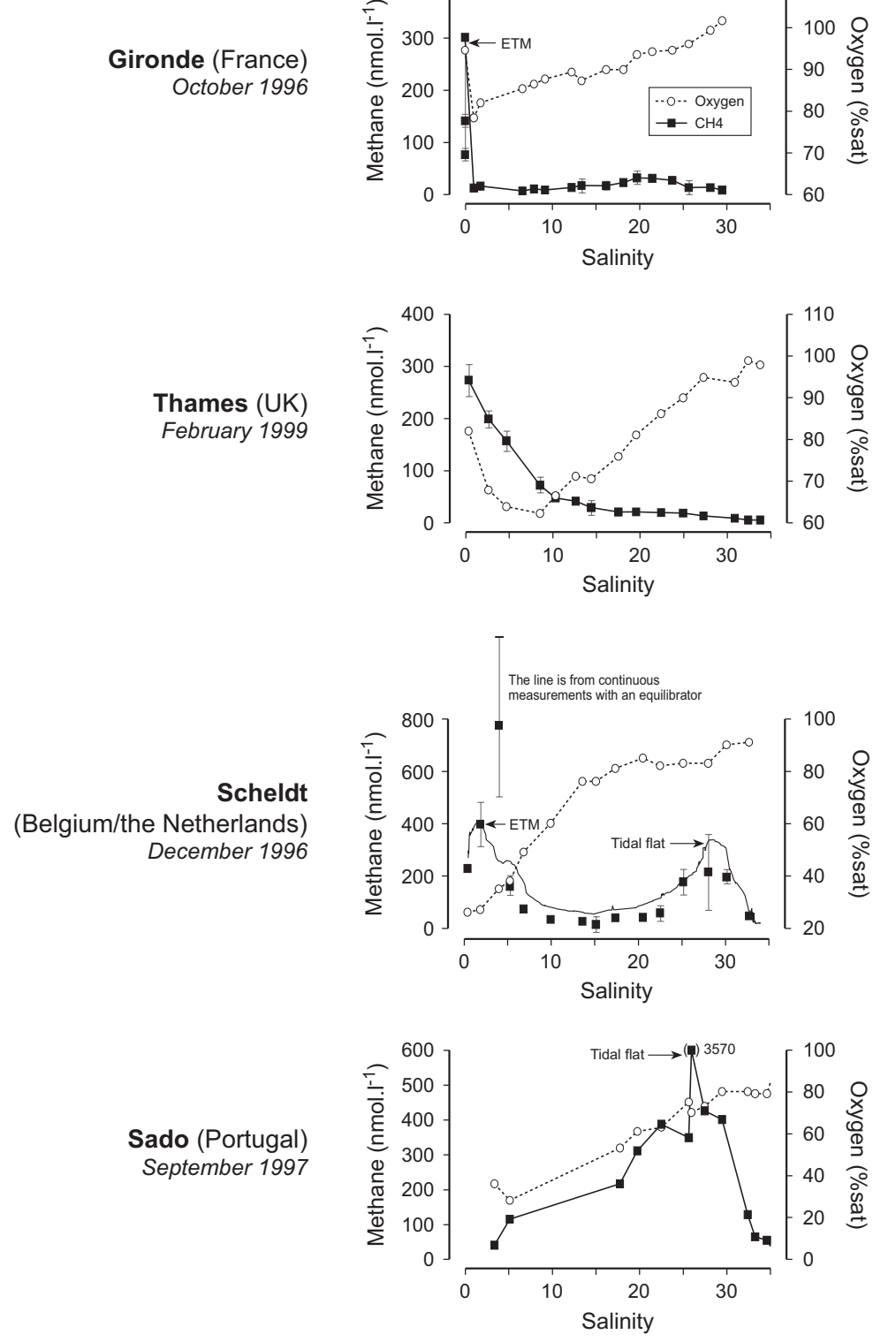

Fig. 7.4. Some examples of non-conservative methane (black squares) and oxygen (open circles) distributions versus salinity measured in European estuaries

Studied during the BIOGEST project (Middelburg et al. 2002). Gironde (France) October 1996; Thames (UK) February 1999; Scheldt (Belgium/the Netherlands) December 1996, the line is from continuous measurements with an equilibrator; Sado (Portugal) September 1997. 
Together with gas evasion, aerobic oxidation is also a significant sink for methane in estuarine waters and sediments, particularly at low salinities. In the Hudson estuary, De Angelis and Scanton (1993) found that methane oxidation in waters could turnover the methane pool in 1.4 to 9 days, but only at salinities below 6 , oxidation rates at higher salinities being 1-2 orders of magnitude lower. Adding salt and filtered seawater to their freshwater samples resulted in a strong inhibition of methane oxidation. In the Columbia river and estuary, similar oxidation rates were measured by Lilley et al. (1996), consistent with a net shift in $\delta^{13} \mathrm{C}_{-} \mathrm{CH}_{4}$ at low to intermediate salinities (Sansone et al. 1999). In the low salinity (3-7) region of the Randers Fjord, a microtidal and shallow estuary in Denmark, Abril and Iversen (2002) observed intense methane oxidation at the sediment surface, which resulted in a net uptake of riverine methane by the estuarine sediment (downward methane flux through the sediment-water interface). They could not detect any methanotrophic activity at ambient concentrations in sediments at salinities 17-23. The relative contribution of microbial oxidation and atmospheric emission as sinks for dissolved methane was estimated in these three systems. The methane emission/oxidation ratio was on average 4 in the Columbia river and estuary (Lilley et al. 1996), ranged between 0.4 and 23 in the Hudson estuary (De Angelis and Scranton 1993) and between 0.8 and 5.1 in the low salinity regions of the Randers fjord (Abril and Iversen 2002). Ratios lower than one were restricted to summer periods, low salinities and high methane concentrations. Abril and Iversen (2002) discussed that wind speed has a multiplicative effect on this ratio: at low wind, methane builds-up in the water, enhancing microbial oxidation (typically a first order process), whereas at high wind, methane is stripped out the water to the atmosphere, decreasing water concentrations and inhibiting oxidation.

When considering the moderate emissions rates from estuarine channels and plumes in Table 7.2, the large contribution to this flux of methane inputs from rivers, tidal flats and marshes, the modest (though significant) contribution of oxidation, it appears that sub-tidal regions of estuaries are environments where methane production is relatively low. Unlike tidal flats and marshes, submerged estuarine sediments have no rooted macrophytes to inject labile organic matter at depths were methanogenesis occurs. In the freshwater area of the White Oak river estuary, Kelley et al (1995) found lower methane production rates in submerged sediments compared to tidal flat sediments. The organic matter undergoes several phases of degradation in the water column and at the sediment surface and looses most of its labile fraction before being incorporated into the methanogenic active zone of the sediment. In ETMs, periodic resuspensions of surface sediments with tidal currents make oxic and suboxic proc- 
esses (nitrate, manganese and iron reductions) dominate the oxidation of organic matter (Abril et al. 1999). In addition, as soon as salinity and sulfate increase, sedimentary carbon remineralization generates in majority dissolved inorganic carbon and little methane (Martens and Goldhaber 1978; Kelley et al. 1990). Nevertheless, biogenic methane production occurs in estuarine channels, as evidenced by the more negative values of $\delta^{13} \mathrm{C}^{-} \mathrm{CH}_{4}$ in the Great Bay estuary (US-New Hampshire) (Sansone et al. 1999). Methane production is also responsible for net methane inputs at very low salinities, observed in macrotidal systems like the Tyne and Humber estuaries (UK) (Upstill-Goddard et al. 2000), and the Gironde and Scheldt estuaries (Fig. 7.4). These regions correspond to the entrance of ETMs, a zone very active for mineralization of riverine organic matter and generally showing the maximum hypoxia.

\subsection{Significance at the Global Scale}

Owing to this large spatial heterogeneity, estimations of carbon dioxide and methane emissions at the global scale suffer from large uncertainties. In addition, there is also a large uncertainty on the surface of world estuaries. To our best knowledge, the only estimation of world estuarine surface available is the one by Woodwell et al. (1973), i.e. $1400.10^{3} \mathrm{~km}^{2}$. They estimated an inner estuarine surface/coast length ratio in the US which varied between $0.12 \mathrm{~km}^{2} \cdot \mathrm{km}^{-1}$ in the North Atlantic coast and $5.97 \mathrm{~km}^{2} \cdot \mathrm{km}^{-1}$ in the Gulf of Mexico with an average of $0.78 \mathrm{~km}^{2} \cdot \mathrm{km}^{-1}$ for the entire US. Then, Woodwell et al. (1973) extrapolated the latter average value to the entire world coastline but added that: "It would be surprising if estimates derived in this way were accurate within $\pm 50 \% "$. Nevertheless, almost all gas emission budgets at the global scale were calculated with this estuarine surface. An average $\mathrm{CO}_{2}$ flux of $100 \mathrm{mmol} \cdot \mathrm{m}^{-2} \cdot \mathrm{d}^{-1}$ (Table 7.1) integrated over this surface gives a global flux of $\sim 600.10^{12} \mathrm{gC} \cdot \mathrm{y}^{-1}$. This first order estimates is however higher than the total organic carbon transported by world rivers $\left(\sim 400.10^{12} \mathrm{gC} \cdot \mathrm{y}^{-1}\right.$ Ludwig et al. 1996). Owing to the fact that only about one half of the particulate organic carbon (representing $170.10^{12} \mathrm{gC} \cdot \mathrm{y}^{-1}$; Ludwig et al. 1996) is generally lost in estuaries (Abril et al. 2002) the overestimation is around a factor 3 to 5. This might be due to an overestimation of the estuarine surface, rather than an overestimation of the flux density from Table 7.1. However, it should also be noted that the estimate of Ludwig et al. (1996) only accounts for fluvial carbon inputs and does not account for lateral inputs (in particular from marshes and flats). No global estimates are at present time available for these, but local studies show they are significant (Cai et al. 1999). Most of the $\mathrm{CO}_{2}$ fluxes 
in estuaries have been reported so far in temperate latitudes, despite the fact that about $60 \%$ of the fresh water discharge and organic carbon inputs occurs at tropical latitudes (Ludwig et al. 1996). Anyhow, the carbon dioxide source from inner estuaries and sources or sinks from riverine plumes represent significant components of the global carbon cycle, which need to be further investigated both in terms of magnitude and in terms of processes involved. Methane emissions from estuaries (excluding tidal marshes) have been recently integrated at the global scale by several authors, using the same estuarine surface from Woodwell et al. (1973). Estimates are 0.8-1.3.10 ${ }^{12} \mathrm{gCH}_{4} \cdot \mathrm{y}^{-1}$ (Bange et al. 1994); 0.9-1.7.10 $\mathrm{gCH}_{4} \cdot \mathrm{y}^{-1}$ (Upstill-Goddard et al. 2000) and 1.8-3.0.10 ${ }^{12} \mathrm{gCH}_{4} \cdot \mathrm{y}^{-1}$ (Middelburg et al. 2002). This is less than $10 \%$ of the global oceanic emission, which itself represents only $1-10 \%$ of all natural and anthropogenic sources (Bange et al. 1994). Thus, estuaries are a very minor contributor to the global methane emissions.

\section{Acknowledgments}

We thank Henri Etcheber (DGO-Bordeaux), Michel Frankignoulle (University de Liège, Belgium), Niels Iversen (Aalborg University), Jack Middelburg (NIOO, the Netherlands) and Roland Wollast (Université Libre de Bruxelles), for their continuous guidance and support during the BIOGEST project. This work benefited from funding by the European Union, through the several doctoral and post-doctoral grants between 1996 and 2001.

\section{References}

Abril G, Etcheber H, Delille B, Frankignoulle M, Borges AV (2003) Carbonate dissolution in the turbid and eutrophic Loire estuary. Mar Ecol Prog Ser 259:129-138

Abril G, Nogueira M, Etcheber H, Cabeçadas G, Lemaire E, Brogueira MJ (2002) Behaviour of organic carbon in nine contrasting European estuaries. Estuar Coast Shelf Sci 54:241-262

Abril G, Iversen N (2002) Methane dynamics in a shallow, non-tidal, estuary (Randers Fjord, Denmark). Mar Ecol Prog Ser 230:171-181

Abril G, Etcheber H, Le Hir P, Bassoullet P, Boutier B, Frankignoulle M (1999) Oxic/anoxic oscillations and organic carbon mineralization in an estuarine maximum turbidity zone (The Gironde, France). Limnol Oceanogr 44:13041315 
Allen GP, Salomon JC, Bassoulet P, Du Penhoat Y, De Grandpré C (1980) Effects of tides on mixing and suspended sediment transport in macrotidal estuaries. Sed Geol 26:69-90

Aller RC (1998) Mobile deltaic and continental shelf muds as suboxic, fluidized bed reactors. Mar Chem 61:143-155

Amouroux D, Roberts G, Rapsomanikis S, Andrea MO (2002) Biogenic gas $\left(\mathrm{CH}_{4}\right.$, $\mathrm{N}_{2} \mathrm{O}$, DMS) emission to the atmosphere from near-shore and shelf waters of the Northwestern Black sea. Est Coast Shelf Sci 54:575-587

Bange HW, Bartell UH, Rapsomanikis S and Andrea MO (1994) Methane in the Baltic and North Seas and a reassessment of the marine emissions of methane. Global Biogeochemical Cycles 8:465-480

Bange HW, Rapsomanikis S and Andrea MO (1996) The Aegean Sea as a source of atmospheric nitrous oxide and methane. Mar Chem 53:41-49

Bange HW, Dahlke S, Ramesh R, Meyer-Reil LA, Rapsomanikis S, Andrea MO (1998) Seasonal study of methane and nitrous oxide in the coastal waters of the southern Baltic Sea. Est Coast Shelf Sci 47:807-817

Bartlett KB, Harris RC, Sebacher DI (1985) Methane flux from coastal marshes. J Geophys Res 90:5710-5720

Bartlett KB, Bartlett DS, Harris RC, Sebacher DI (1987) Methane emissions along a salt marsh salinity gradient. Biogeochemistry 4:183-202

Borges AV, Frankignoulle M (2002) Distribution and air-water exchange of carbon dioxide in the Scheldt plume off the Belgian coast. Biogeochemistry 59:41-67

Borges AV, Delille B, Schiettecatte LS, Gazeau F, Abril G, Frankignoulle M (2004a) Gas transfer velocities of $\mathrm{CO}_{2}$ in three European estuaries (Randers Fjord, Scheldt and Thames). Submitted

Borges AV, Vandenborght JP, Schiettecatte LS, Gazeau F, Ferrón-Smith S, Delille B, Frankignoulle M (2004b) Variability of the gas transfer velocity of $\mathrm{CO}_{2}$ in a macrotidal estuary (The Scheldt). Submitted

Bouillon S, Frankignoulle M, Dehairs F, Velimirov B, Eiler A, Abril G, Etcheber $\mathrm{H}$, Borges AV (2003) Inorganic and organic carbon biogeochemistry in the Gautami Godavari estuary (Andhra Pradesh, India) during pre-monsoon: the local impact of extensive mangrove forests. Glob Biogeochem Cycles 17:1114

Brasse S, Nellen M, Seifert R, Michaelis W (2002) The carbon dioxide system in the Elbe estuary. Biogeochemistry 59:25-40

Cai WJ, Wang Y (1998) The chemistry, fluxes and sources of carbon dioxide in the estuarine waters of the Satilla and Altamaha Rivers, Georgia. Limnol Oceanogr 43:657-668

Cai WJ, Pomeroy LR, Moran MA, Wang Y (1999) Oxygen and carbon dioxide mass balance for the estuarine-intertidal marsh complex of five rivers in the southeastern U.S. Limnol Oceanogr 44:639-649

Cai WJ, Wiebe WJ, Wang Y, Sheldon JE (2000) Intertidal marsh as a source of dissolved inorganic carbon and a sink of nitrate in the Satilla River-estuarine complex in the southeastern US. Limnol Oceanogr 45:1743-1752 
Cameron WM, Pritchard DW (1963) Estuaries. In: Hill MN (ed) The Sea, vol 2. Wiley-Interscience, New York, pp 306-324

Capone DG, Kiene RP (1988) Comparison of microbial dynamics in marine and freshwater sediments: contrasts in anaerobic carbon catabolism. Limnol Oceanogr 33:725-749

Carini S, Weston N, Hopkinson C, Tucker J, Giblin A, Vallino J (1996) Gas exchange rates in the Parker river estuary, Massachussets. Biol Bull 191:333334

Chanton JP, Martens CS, Kelley CA (1989) Gas transport from methanesaturated, tidal freshwater and wetland sediments. Limnol Oceanogr 34:807819

Clark JF, Wanninkhof R, Schlosser P, Simpson HJ (1994) Gas exchange rates in the tidal Hudson River using a dual tracer technique. Tellus 46B:274-285

Cloern JE (1996) Phytoplankton bloom dynamics in coastal ecosystem: a review with some general lessons from sustained investigation of San Francisco Bay, California. Rev Geophys 34:127-168

Cole JJ, Caraco NF (2001) Carbon in catchments: connecting terrestrial carbon losses with aquatic metabolism. Mar Freshwater Res 52:101-110

Crump BC, Baross JA, Simenstad CA (1998) Dominance of particle-attached bacteria in the Columbia River estuary, USA. Aquat Microbiol Ecol 14:7-48

Dame R, Chrzanowski T, Bildsteine K, Kjerfve B, McKellar H, Nelson D, Spurrier J, Stancyk S, Stevenson H, Vernberg J, Zingmark R (1986) The outwelling hypothesis and North Inlet, South Carolina. Mar Ecol Prog Ser 33:217229

De Angelis MA, Lilley MD (1987) Methane in surface waters of Oregon estuaries and rivers. Limnol Oceanogr 32:716-722

De Angelis MA, Scranton MI (1993) Fate of methane in the Hudson river and estuary. Glob Biogeochem Cycles 7:509-523

Delaune RD, Pezeshki SR (2003) The role of soil organic carbon in maintaining surface elevation in rapidly subsiding U.S. Gulf of Mexico coastal marshes. Water Air Soil Poll 3:167-179

Frankignoulle M, Bourge I, Wollast R (1996) Atmospheric $\mathrm{CO}_{2}$ fluxes in a highly polluted estuary (The Scheldt). Limnol Oceanogr 41:365-369

Frankignoulle M, Abril G, Borges A, Bourge I, Canon C, Delille B, Libert E, Théate JM (1998) Carbon dioxide emission from European estuaries. Science 282:434-436

Frankignoulle M, Middelburg J (2002) Biogases in tidal European estuaries: the BIOGEST project. Biogeochemistry 59:1-4

Gattuso JP, Frankignoulle M, Wollast R (1998) Carbon and carbonate metabolism in coastal aquatic ecosystems. Ann Rev Ecol Syst 29:405-434

Goni MA, Thomas KA (2000) Sources and transformation of organic matter in surface soils and sediments from a tidal estuary (North Inlet, South Carolina, USA). Estuaries 23:548-564

Goosen NK, Kromkamp J, Peene J, van Rijswijk P, van Breugel P (1999) Bacterial and phytoplankton production in the maximum turbidity zone of three 
European estuaries: the Elbe, Westerschelde and Gironde. J Mar Sys 22:151171

Ittekkot V, Lanne RWPM (1991) Fate of riverine particulate organic matter. In: Degens ET, Kempe S, Richey R (eds) Biogeochemistry of major world rivers, SCOPE 42, J Wiley and Sons, New York, pp 233-242

Jayakumar DA, Naqvi SWA, Narvekar PV, George MD (2001) Methane in coastal and offshore water of the Arabian Sea. Mar Chem 74:1-13

Jones JB, Mulholland PJ (1998a) Carbon dioxide variation in a hardwood forest stream: an integrative measure of whole catchment soil respiration. Ecosyst $1: 183-196$

Jones JB, Mulholland PJ (1998b) Methane input and evasion in a hardwood forest stream: effects of subsurface flow from shallow and deep pathways. Limnol Oceanogr 43:1243-1250

Justic D, Rabalais N, Turner RE (1995) Stoichiometric nutrient balance and origin of coastal eutrophication. Mar Poll Bull 30:41-46

Kauppila P, Meeuwig JJ, Pitkänen H (2003) Predicting oxygen in small estuaries of the Baltic Sea: a comparative approach, Estuar Coast Shelf Sci 57:11151126

Keil RG, Mayer LM, Quay PD, Richey JE, Hedges JI (1997) Loss of organic matter from riverine particles in deltas. Geochim Cosmochim Acta 61:1507-1511

Kelley CA, Marteens CS, Chanton JP (1990) Variations in sedimentary carbon remineralization rates in the White Oak River estuary, North Carolina. Limnol Oceanogr 35:372-383

Kelley CA, Martens CS, Ussler W III (1995) Methane dynamics across a tidally flooded riverbank margin. Limnol Oceanogr 40:1112-1129

Ketchum RH (1983) Estuarine characteristics. In: Ketchum RH (ed) Ecosystems of the world 26, Elsevier, pp 1-14

Kremer JN, Reischauer A, D'Avanzo C (2003) Estuary-specific variation in the air-water gas exchange coefficient for oxygen. Estuaries 26:829-836

Körtzinger A (2003) A significant $\mathrm{CO}_{2}$ sink in the tropical Atlantic Ocean associated with the Amazon River plume. Geophys Res Lett 30:2287

Lilley MD, De Angelis MA, Olson (1996) Methane concentrations and estimated fluxes from Pacific Northwest rivers. In: Adams DD, Seitzinger SP, Crill PM (eds) Cycling of reduced gases in the Hydrosphere, E. Schweizerbart'sche Verlagbuchhandlung, Stuttgart, pp 187-196

Lipschultz F (1981) Methane release from a brackish intertidal Salt-marsh embayment of Chesapeake Bay, Maryland. Estuaries 4:143-145

Ludwig W, Probst JL, Kempe S (1996) Predicting the oceanic input of organic carbon by continental erosion. Glob Biogeochem Cycles 10:23-41

Magenheimer JF, Moore TR, Chmura GL, Daoust RJ (1996) Methane and carbon dioxide flux from a macrotidal salt marsh, Bay of Fundy, New Brunswick. Estuaries 19:139-145

Marino R, Howard RW (1993) Atmospheric oxygen exchange in the Hudson river: dome measurements and comparison with other natural waters. Estuaries 16:433-445 
Martens CS, Goldhaber (1978) Early diagenesis in transitional sedimentary environments of the White Oak River estuary, North Carolina. Limnol Oceanogr 23:428-441

Meybeck M (1993) Riverine transport of atmospheric carbon: sources, global typology and budget. Water Air Soil Poll 70:443-463

Morris JT, Whiting GJ (1986) Emission of gaseous carbon dioxide from SaltMarsh sediments and its relation to other carbon losses. Estuaries 9:9-19

Middelburg JJ, Klaver G, Nieuwenhuize J, Wielemaker A, Haas W, Vlut T, Van der Nat FJWA (1996) Organic matter mineralization in intertidal sediments along an estuarine gradient. Mar Ecol Prog Ser 132:157-168

Middelburg JJ, Nieuwenhuize J, Iversen N, Høegh N, de Wilde H, Helder W, Seifert R, Christof O (2002) Methane distribution in tidal estuaries. Biogeochem 59:95-119

Neal C, House WA, Jarvie HP, Eatherall A (1998) The significance of dissolved carbon dioxide in major lowland rivers entering the North Sea. Sci Total Environ 210/211:187-203

Nienhuis PH (1992) Eutrophication, water management, and the functioning of Dutch estuaries and coastal lagoons. Estuaries 15:538-548

O'Connor DJ, Dobbins WE (1958) Mechanism of reaeration in natural streams. Transactions of the American Society of Civil Engineering 123:641-684

Park PK, Hager SW, Cissel MC (1969) Carbon dioxide partial pressure in the Columbia River. Science 166:867-868

Perillo GME (1995) Definition and geomorphologic classifications of estuaries. In: Perillo GME (ed.) Geomorphology and Sedimentology of estuaries, Developments in Sedimentology 53, Elsevier Science BV

Raymond PA, Caraco NF, Cole JJ (1997) Carbon dioxide concentration and atmospheric flux in the Hudson river. Estuaries 20:381-390

Raymond PA, Cole JJ (2001) Gas exchange in rivers and estuaries: choosing a gas transfer velocity. Estuaries 24:312-317

Raymond PA, Bauer J, Cole JJ (2000) Atmospheric $\mathrm{CO}_{2}$ evasion, dissolved inorganic carbon production and net heterotrophy in the York River estuary. Limnol Oceanogr 45:1707-1717

Reid PC, Lancelot C, Gieskes WWC, Hagmeier E, Weichart G (1990) Phytoplankton of the North Sea and its dynamics: a review. Neth J Sea Res 26: 295331

Richey JE, Devol AH, Wofsy SC, Victoria R, Riberio MNG (1988) Biogenic gases and the oxidation of carbon in Amazon river and floodplain waters. Limnol Oceanogr 33:551-561

Richey JE, Melack JM, Aufdenkampe AK, Ballester VM, Hess LL (2002) Outgassing from Amazonian rivers and wetlands as a large tropical source of atmospheric $\mathrm{CO}_{2}$. Nature 416:617-620

Sansone FJ, Rust TM, Smith SV (1998) Methane distribution and cycling in Tomales Bay, California. Estuaries 21:66-77

Sansone FJ, Holmes ME, Popp BN (1999) Methane stable isotopic ratios and concentrations as indicators of methane dynamics in estuaries. Glob Biogeochem Cycles 13:463-474 
Sarma VVSS, Kumar MD, Manerikar (2001) Emission of carbon dioxide from a tropical estuarine system, Goa, India. Geophys Res Lett 28:1239-1242

Scranton MI, McShane K (1991) Methane fluxes in the southern North Sea: the role of European rivers. Cont Shelf Res 11:37-52

Smith SV, Hollibaugh JT (1993) Coastal metabolism and the oceanic organic carbon cycle. Rev Geophys 31:75-89

Stumm W, Morgan JJ (1996) Aquatic Chemistry. Chemical equilibria and rates in natural waters. In: Schnoor J, Zehnder A (eds) Environmental Science and Technology, Wiley and Sons. $1024 \mathrm{p}$.

Ternon JF, Oudot C, Dessier A, Diverres D (2000) A seasonal tropical sink for atmospheric $\mathrm{CO}_{2}$ in the Atlantic ocean: the role of the Amazon river discharge. Mar Chem 68:183-201

Uncles RJ (2002) Estuarine Physical Processes Research: Some Recent Studies and Progress. Estuar Coast Shelf Sci 55:829-856

Upstill-Goddard RC, Barnes J, Frost T, Punshon S and Owens NJP (2000) Methane in the Southern North Sea: low salinity inputs, estuarine removal and atmospheric flux. Glob Biogeochem Cycles 14:1205-1217

Veyssy E, Etcheber H, Lin RG, Buat-Menard P, Maneux E (1999) Seasonal variations and origins of particulate organic carbon in the lower Garonne River at La Réole (SW France). Hydrobiol 391:113-126

Van der Nat FJWA, Middelburg JJ (2000) Methane emissions from tidal freshwater marshes. Biogeochem 49:103-121

Wanninkhof R (1992) Relationship between gas exchange and wind speed over the ocean. J Geophys Res 97:7373-7382

Widdows J, Brown S, Brinsley MD, Salkeld PN, Elliot M. (2000) Temporal changes in intertidal sediment erodability: influence of biological and climatic factors. Cont Shelf Res 20:1275-1289

Woodwell PM, Rich PH, Hall CAS (1973) Carbon in estuaries. In: PM Woodwell, EV Pecan (eds) Carbon and the Biosphere, Springfield, Virginia, pp 221-240

Wollast R (1983) Interaction in estuaries and coastal waters. In: Bolin B, Cook RB (eds) The major biogeochemical cycles and their interactions, SCOPE, Wiley, pp 385-407

Zappa CJ, Raymond PA, Terray EA, McGillis WR (2003) Variation in surface turbulence and the gas transfer velocity over a tidal cycle in a macro-tidal estuary. Estuaries 26(6):1401-1415 